\title{
Effect of inoculation of am fungi and beneficial microorganisms on growth and nutrient uptake of Eleusine coracana (L.) Gaertn. (Finger millet)
}

\author{
K. Ramakrishnan*, G. Bhuvaneswari \\ Department of Botany, Faculty of Science, Annamalai University, Chidambaram, Tamil Nadu, India \\ *E-mail address: drkrkrishnan@gmail.com
}

\begin{abstract}
Biofertilizers have been used as sources to improve plant nutrients in sustainable agriculture. Biofertilizers are low cost, renewable sources of plant nutrients which supplement chemical fertilizers. Mycorrhizal fungi are a major component of agricultural natural resources and members of kingdom fungi. The term 'mycorrhiza' is derived from Greek word which means 'fungus root'. Earthen pot experiments were carried out to study the inoculation effect of Arbuscular Mycorrhizal (AM) fungi (Glomus mossease), Azospirillium brasilense and PSB on plant height, dry weight of root and shoot, per cent root colonization, spore number, $P$ and $N$ uptake. Experimental pots were filled with 4 kegs of sterilized soil and maintained in green house at $25-30{ }^{\circ} \mathrm{C}$ temperature. Single inoculation of AM fungi and combined inoculation of AM fungi with Azospirillium brasilense or PSB was found to be moderately increased in all the growth parameters. However triple inoculation of $A M$ fungi, Azospirillium brasilense and PSB was found to have highest growth parameters.
\end{abstract}

Keywords: Glomus fasciculatum; Azospirillium brasilense; per cent colonization; biomass production

\section{INTRODUCTION}

Before attaining the true management of soil microbes, it is essential to understand better the interaction between plants and microbes in the soil around the roots. Management of soil microbes is necessary to optimize $\mathrm{N}$ and $\mathrm{P}$ nutrition of plants. There are extensive microbial activities in rhizosphere soil which is colonized by a wide range of microbes with important effects on plant nutrition, growth and health. Among these micro-organisms the importances of mycorrhiza deserve special attention. The term 'mycorrhiza' is derived from Greek word which means 'fungus root'. Arbuscular Mycorrhizal (AM) fungi are found in most of the soils around the world, and they form association with $80 \%$ of all terrestrial plant roots Harley J. L. 1987. The beneficial effects of AM fungi symbiotic association on the growth of plants are well known Smith et al. 1996, Lakshman H. C. et al. 2009. Arbuscular mycorrhizal fungi help in water regulation of plants by extending their hyphae towards the available moisture zone for continuous water absorption and translocation them to plants. Arbuscular mycorrhizal association can affect the host plants in terms of stomata movement and photosynthesis of leaves and has been shown to increase the rate of transpiration, 
photosynthesis and chlorophyll content (Panwar, J. D. S. 1991). Most land plants are symbiotic with Arbuscular mycorrhizal fungi (AMF) and $\mathrm{N}_{2}$ fixing bacteria, which taken up mineral nutrients from the soil and exchange them with plants photo synthetically fixed carbon. Arbuscular mycorrhizal fungi are regular component of rhizosphere micro flora in natural ecosystem and are necessary for sustainable plant soil systems by establishing symbiotic associations with most land plants and form mycorrhizae. AM fungi inhabit a variety of ecosystems including agriculture lands, forest, grasslands and many stressed environments.

\section{Biofertilizers}

Bio-fertilizers are being essential component of organic farming. These are the preparations containing live or latent cells of efficient strains of nitrogen fixing, phosphate solubilizing or cellulolytic micro-organisms used for application to seed, soil or composting areas with the objective of accelerating microbial processes which augment the availability of nutrients that can be easily absorbed by plants. They are in fact being promoted to harvest the naturally available, biological system of nutrient mobilization (Venkatashwarlu, 2008). The role and importance of Biofertilizers in sustainable crop production has been reviewed by several authors (Biswas et al. 1985; Wani and Lee, 1995; Katyal et al. 1994).However Boifertilizer is most commonly referred to the use of soil micro organisms to increase the availability and uptake of mineral nutrients for plants. So it is necessary to define the term" Boifertilizer." There is a proposal that biofertilizer be defined as a substance which contains living micro-organisms which colonies the rhizosphere or the interior of the plant and promotes growth by increasing the supply or availability of primary nutrient and /growth stimulus to the target crop, when applied to seed, plants surface or soil.

In fact, the rhizosphere is a heterogeneous, continuous and natural habitat in which different types of interactions occur between soil microbes and plants. The beneficial plant microbe interaction in the rhizosphere is the primary determinants of plant health and soil fertility. Concentrated efforts are being made worldwide to develop nutrient use-efficient crop cultivars responsive to bio-fertilizers to increase crop yield and also to maintain soil good health. It is indicated that plants might select the AMF and plant growth promoting bacteria such as nitrogen fixers. The current emphasis is on sustainable agriculture, which uses less of chemical inputs like fertilizers and pesticides having adverse effect on soil health, fertility and environment (Lakshman. H. C. et al, 2007). Thus, use of microbial inoculants play an important role in sustainable agriculture. Arbuscular mycorrhizal fungi are known to improve the nutritional status, growth and development of plants, protect plant against root pathogens and offer drought resistance to drought and salinity (Jeffries P. et al., 1987).

Eleusine Coracana Gaertn. (Finger millet) is commonly called as finger millet or African millet. This is the third important millet of India, originated from Africa, later migrated to south East Asia. The most striking feature, which made finger millet an important dry land crop, is its resilience and ability to withstand adverse weather conditions when grown in soils having poor water holding capacity. Finger millet is the third most important millet in India (locally called as Ragi), next to sorghum and pearl millet, covering an area of 2 million hectares with annual production of 2.15 million tones. Finger millet grown on marginal land provides a valuable resource in times of famine. Its grain tastes good and is nutritionally rich (compared to cassava, plantain, polished rice and maize meal) as it contains high levels of calcium, iron and manganese. The flour obtained by grinding the grain is used for preparing cakes, porridge and pudding etc. the grain is used for preparing fermented beverages such as beer. The stalks are used as fodder for milking cattle. The millet straw is 
also an important livestock feed, building material and fuel. Finger millet contains methionine, an essential amino acid lacking in the diets of hundreds of millions of the poor who rely mostly on starchy staples. The finger millet contains a low glycemic index and has no gluten, which makes it suitable for diabetics and people with digestive problems.

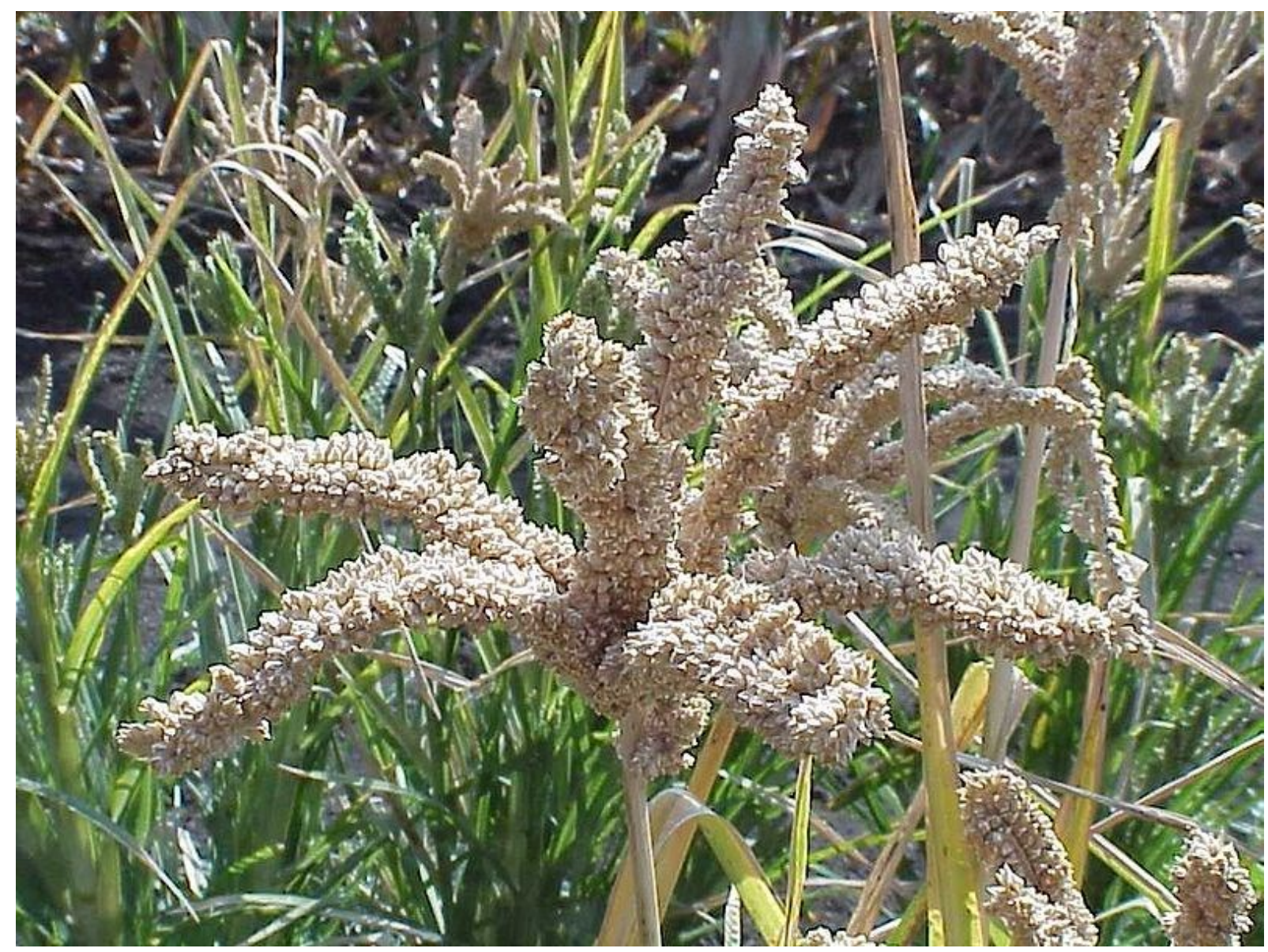

Photo 1. Eleusine coracana (L.) Gaertn.

The effective fertilizer recommendation should consider crop needs and nutrients already available in the soil. Among various methods of fertilizer recommendation such as general recommended dose soil test based recommendation, critical value approach, etc., the soil test crop response approach for targeted yield is unique in indicating both soil test based fertilizer dose and the level of yield that can be achieved with good agronomic practices. Targeted yield concept strikes a balance between fertilizing the crop and fertilizing the soil. Interaction of Arbuscular mycorrhizal (AM) fungi with soil organisms is a well known phenomenon. Several studies in recent years have explored the interaction between AM Fungi and rhizobium on leguminous hosts (Lakshman H. C., Patil G. B., Hosamani P. A., Kadam L. B., et al. 2005). However there is very less report on the interaction of AM fungi with other microorganisms such as Azospirillium and Aztobacter in finger millet varieties that play a significant role in plant growth. However there is very less report on the interaction of AM fungi with other microorganisms such as Azospirillium and Aztobacter in finger millet varieties that play a significant role in plant growth. Soil microorganisms like Azotobacter and Azospirillium are free living $\mathrm{N}^{2}$ fixing bacteria which can successfully grown in the 
rhizophoric zone of crops and fix $10-20 \mathrm{~kg} \cdot \mathrm{Nha}^{-1}$ cropping season. Besides $\mathrm{N}^{2}$ fixation these bacteria synthesize and secret considerable amounts of biologically active substance like gluconic acid and the ability to direct phosphate solubilization which enhances root growth of plants (Rodriguez et. al. 2004). The potential of these microbes as a bio fertilizers has been investigated in the present. The potential of these microbes as a Biofertilizers has been investigated in the present work. In the view of above facts, a study on refining the integrated plant nutrient supply on basis was conducted with the following objectives.

1. To study the effect of AM fungi and bio fertilizer by different approaches on growth and yield of finger millet.

2. To study the effect of bio-fertilizers (Azatobacter and Phosphorus Solubilizing Bacteria) inoculation on growth and yield of finger millet.

\section{MATERIALS AND METHODS}

The pot experiments were conducted in triplicate. Each pot measuring about $30 \mathrm{~cm}$ in diameter were filled with soil and sand in the ratio of $2: 1$ which was sterilized by fumigating with $5 \%$ methyl bromide. The following treatments were given to the experimental pots. Bio - fertilizer cultures were mixed with water and the healthy 25 days old finger millet seedlings were selected and the roots were washed with water and then dipped in the respective Biofertilizer culture for 30 minutes. Bio-fertilizer treated seedlings were then transplanted in the main field as per the treatment details.

The population of Aztobacter in the soil sample collected from experimental site was enumerated by standard dilution plating technique using Wakman's medium 77 . The plates were incubated at $30^{\circ} \mathrm{C}$ for 4-5 days and the number of colonies were counted and expressed per gram of soil. Similarly, the population of phosphate solubilizing microorganisms in soil samples collected from experimental site was enumerated by standard dilution plating technique using Sperber's hydroxyapatite medium. The plates were incubated for 4-5 days and the number of colonies were counted and expressed per gram of soil.

\section{Treatments:}

1. Control

2. AM fungi

3. AM fungi + Azospirillium brasilense

4. AM fungi + Bacillus polymyxa (PSB)

5. AM fungi + Azospirillium brasilense + Bacillus polymyxa (PSB)

Regular watering of experimental plants was done to maintain soil moisture. Periodical data on growth parameters were recorded at 30,60, 90 days interval. Parameters like plant height, dry weight of shoot and root, per cent root colonization. Nitrogen was determined by microkjeldal and phosphorous was determined by phosphoric acid yellow Colour method (Bremner, J. M. 1960). 


\section{Estimation of mycorrhizal colonization:}

Representative samples of the fresh roots were taken immediately after harvest, washed, cut into $1 \mathrm{~cm}$ pieces, and fixed by formalin acetic-acid alcohol solution. Root samples were cleared with $10 \% \mathrm{KOH}$ solution and stained with $0.05 \%$ trypan blue in lacto phenol (Phillips and Hayman, 1970), and microscopically examined for root colonization. The mycorrhizal colonization was evaluated by using the method of Giovannetti and Mosse (1980). Data are given as percentage of root length colonized.

$$
\text { Percentage of AM infection }=\frac{\text { Root length infected }}{\text { Root length observed }} \times 100
$$

Number of spores in the soil surrounding the roots was determined by the wet sieving and decanting technique (Gerdemann J. W., Nicolson, 1963) and identified with the help of manual (Schenck N. C., Perez Y. 1990)

\section{Statistical Analysis:}

Differences among treatments were analyzed for main effects (AM fungi and Microorganisms) and their interaction by standard deviation $( \pm \mathrm{SD})$. All values are means of three replicates. Significant differences were calculated using the least-significant-difference (LSD) test at $\mathrm{p}<5 \%$ level.

Table 1. Showing physico -chemical properties of soil used for the pot experiments.

\begin{tabular}{|c|c|}
\hline Characteristic & Garden soil \\
\hline $\mathrm{pH}$ & 6.7 \\
\hline Soil moisture (\%) & 28.04 \\
\hline Organic matter (\%) & 0.82 \\
\hline $\mathrm{E} . \mathrm{C}$ & 0.97 \\
\hline $\mathrm{N}$ & 1.42 \\
\hline $\mathrm{P}$ & 0.27 \\
\hline $\mathrm{K}$ & 2.42 \\
\hline $\mathrm{Zn}$ & 2.03 \\
\hline $\mathrm{Cu}$ & 1.06 \\
\hline $\mathrm{Mg}$ & 1.43 \\
\hline $\mathrm{Pb}$ & 0.95 \\
\hline
\end{tabular}




\section{RESULTS AND DISCUSSION}

The results of soil analysis and the effects of different treatments of inoculam (single, dual and triple) have been presented in Table 2. In the present investigation combined inoculation of AM Fungi with Azospirillium and Azotobacter significantly increased all the growth parameters and yield in the finger millet. Azospirillum is an associative symbiotic nitrogen fixing bacteria. There was also increase in $\mathrm{P}$ and $\mathrm{N}$ uptake in shoots and with per cent root colonization in roots and spore number over the control ones.

Plants treated with dual inoculum of AM fungi and azosprillium showed higher $\mathrm{P}$ uptake when compared to control plants. Growth parameters such as plant height, dry weight of root and shoot, per cent root colonization (Fig. C), spore number was high in AM fungi + Azosprillium treated plants than that of AM fungi and bacillus polymyxa treated plants (Table 2). Tripartite inoculation of mycorrhizal fungi, Azospirillium and phosphate solubilizing bacteria stimulated increase in plant growth parameters.

Phosphorous and nitrogen content was high when compared to plants treated with dual inoculums. Increase in AM per cent of colonization was observed only after 90 days of mycorrhizal inoculation. The control plants failed to show significant growth due to the absence of AM fungal colonization, phosphate solubilizing bacteria and nitrogen fixing organisms. The use of phosphate solubilizing bacteria as inoculants simultaneously increases P uptake by the plant and crop yield.

The effect of tripartite association of mycorrhizal fungi, nitrogen fixing bacteria and phosphate solubilizing bacteria on growth and uptake of ' $P$ ' and ' $N$ ' has been a subject of interest in recent days. It is well known that the magnitude of plant response to any microbial inoculation is greatly affected by the Phosphorous $(\mathrm{P})$ and nitrogen $(\mathrm{N})$ content of the soil (Paula M.A, et al., 1992).

Table 2. Showing the effect of AM Fungi, PSB (Bacillus polymyxa) Azospirillium brasilense, on the growth response of Eleusine Coracana (Finger millet). ( $30^{\text {th }} \cdot 60^{\text {th }} .90^{\text {th }}$ day's plant).

\begin{tabular}{|c|c|c|c|c|c|c|c|}
\hline Treatments & Plant height & DWS & DWR & $\begin{array}{l}\% \text { of root } \\
\text { colonization }\end{array}$ & $\begin{array}{l}\text { Spore } \\
\text { number }\end{array}$ & P uptake & $\mathrm{N}$ uptake \\
\hline \multicolumn{8}{|c|}{$30^{\text {th }}$ DAYS } \\
\hline Control & $\begin{array}{c}6.52 \\
\pm 0.05\end{array}$ & $\begin{array}{c}0.33 \\
\pm 0.03\end{array}$ & $\begin{array}{c}0.28 \\
\pm 0.06\end{array}$ & 0.00 & 0.00 & $\begin{array}{c}1.36 \\
\pm 0.02\end{array}$ & $\begin{array}{c}3.12 \\
\pm 0.10\end{array}$ \\
\hline AM fungi & $\begin{array}{l}10.27 \\
\pm 0.02\end{array}$ & $\begin{array}{c}0.52 \\
\pm 0.02\end{array}$ & $\begin{array}{c}0.37 \\
\pm 0.02\end{array}$ & $\begin{array}{l}32.12 \\
\pm 0.07\end{array}$ & $\begin{array}{l}36.14 \\
\pm 0.03\end{array}$ & $\begin{array}{c}2.11 \\
\pm 0.01\end{array}$ & $\begin{array}{c}4.09 \\
\pm 0.02\end{array}$ \\
\hline $\mathrm{AMF}+\mathrm{AZ}$ & $\begin{array}{l}12.33 \\
\pm 0.04\end{array}$ & $\begin{array}{c}0.63 \\
\pm 0.05\end{array}$ & $\begin{array}{c}0.40 \\
\pm 0.02\end{array}$ & $\begin{array}{l}41.12 \\
\pm 0.02\end{array}$ & $\begin{array}{l}48.23 \\
\pm 0.01\end{array}$ & $\begin{array}{c}2.23 \\
\pm 0.02\end{array}$ & $\begin{array}{c}5.24 \\
\pm 0.01\end{array}$ \\
\hline $\mathrm{AMF}+\mathrm{PSB}$ & $\begin{array}{l}14.10 \\
\pm 0.01\end{array}$ & $\begin{array}{c}0.69 \\
\pm 0.04\end{array}$ & $\begin{array}{c}0.44 \\
\pm 0.01\end{array}$ & $\begin{array}{l}48.14 \\
\pm 0.03\end{array}$ & $\begin{array}{l}53.12 \\
\pm 0.01\end{array}$ & $\begin{array}{c}2.44 \\
\pm 0.02\end{array}$ & $\begin{array}{c}5.30 \\
\pm 0.03\end{array}$ \\
\hline $\begin{array}{c}\mathrm{AMF}+\mathrm{AZ} \\
\quad+\mathrm{PSB}\end{array}$ & $\begin{array}{l}17.08 \\
\pm 0.02\end{array}$ & $\begin{array}{c}0.75 \\
\pm 0.03\end{array}$ & $\begin{array}{c}0.47 \\
\pm 0.06\end{array}$ & $\begin{array}{l}50.14 \\
\pm 0.04\end{array}$ & $\begin{array}{l}58.11 \\
\pm 0.04\end{array}$ & $\begin{array}{c}3.08 \\
\pm 0.03\end{array}$ & $\begin{array}{c}5.42 \\
\pm 0.02\end{array}$ \\
\hline
\end{tabular}




\begin{tabular}{|c|c|c|c|c|c|c|c|}
\hline Treatments & Plant height & DWS & DWR & $\begin{array}{c}\% \text { of root } \\
\text { colonization }\end{array}$ & $\begin{array}{l}\text { Spore } \\
\text { number }\end{array}$ & P uptake & $\mathrm{N}$ uptake \\
\hline \multicolumn{8}{|c|}{$60^{\text {th }}$ DAYS } \\
\hline Control & $\begin{array}{l}11.31 \\
\pm 0.14\end{array}$ & $\begin{array}{c}0.42 \\
\pm 0.21\end{array}$ & $\begin{array}{c}0.37 \\
\pm 0.11\end{array}$ & 0.00 & 0.00 & $\begin{array}{c}3.33 \\
\pm 0.02\end{array}$ & $\begin{array}{c}6.33 \\
\pm 0.04\end{array}$ \\
\hline AM fungi & $\begin{array}{l}20.21 \\
\pm 0.04\end{array}$ & $\begin{array}{c}1.24 \\
\pm 0.24\end{array}$ & $\begin{array}{c}0.44 \\
\pm 0.20\end{array}$ & $\begin{array}{l}50.02 \\
\pm 0.02\end{array}$ & $\begin{array}{l}60.31 \\
\pm 0.30\end{array}$ & $\begin{array}{l}4.63 \\
\pm 0.01\end{array}$ & $\begin{array}{c}8.12 \\
\pm 0.02\end{array}$ \\
\hline $\mathrm{AMF}+\mathrm{AZ}$ & $\begin{array}{l}22.36 \\
\pm 0.02\end{array}$ & $\begin{array}{c}1.28 \\
\pm 0.11\end{array}$ & $\begin{array}{c}0.52 \\
\pm 0.21\end{array}$ & $\begin{array}{l}54.32 \\
\pm 0.21\end{array}$ & $\begin{array}{l}63.12 \\
\pm 0.12\end{array}$ & $\begin{array}{c}5.33 \\
\pm 0.03\end{array}$ & $\begin{array}{c}9.11 \\
\pm 0.03\end{array}$ \\
\hline $\mathrm{AMF}+\mathrm{PSB}$ & $\begin{array}{l}24.41 \\
\pm 0.08\end{array}$ & $\begin{array}{c}1.36 \\
\pm 0.21\end{array}$ & $\begin{array}{c}0.64 \\
\pm 0.12\end{array}$ & $\begin{array}{l}58.32 \\
\pm 0.32\end{array}$ & $\begin{array}{l}66.04 \\
\pm 0.33\end{array}$ & $\begin{array}{l}66.21 \\
\pm 0.02\end{array}$ & $\begin{array}{c}9.43 \\
\pm 0.02\end{array}$ \\
\hline $\begin{array}{c}\mathrm{AMF}+\mathrm{AZ} \\
\quad+\mathrm{PSB}\end{array}$ & $\begin{array}{l}28.21 \\
\pm 0.11\end{array}$ & $\begin{array}{c}1.41 \\
\pm 0.21\end{array}$ & $\begin{array}{c}0.71 \\
\pm 0.04\end{array}$ & $\begin{array}{l}63.21 \\
\pm 0.12\end{array}$ & $\begin{array}{l}70.41 \\
\pm 0.08\end{array}$ & $\begin{array}{l}70.00 \\
\pm 0.13\end{array}$ & $\begin{array}{l}10.12 \\
\pm 0.02\end{array}$ \\
\hline
\end{tabular}

\begin{tabular}{|c|c|c|c|c|c|c|c|}
\hline Treatments & Plant height & DWS & DWR & $\begin{array}{c}\% \text { of root } \\
\text { colonization }\end{array}$ & $\begin{array}{c}\text { Spore } \\
\text { number }\end{array}$ & P uptake & $\mathrm{N}$ uptake \\
\hline \multicolumn{8}{|c|}{$90^{\text {th }}$ DAYS } \\
\hline Control & $\begin{array}{l}16.14 \\
\pm 0.13\end{array}$ & $\begin{array}{c}0.49 \\
\pm 0.31\end{array}$ & $\begin{array}{c}0.40 \\
\pm 0.21\end{array}$ & 0.00 & 0.00 & $\begin{array}{l}4.16 \\
\pm 0.04\end{array}$ & $\begin{array}{c}8.33 \\
\pm 0.04\end{array}$ \\
\hline AM fungi & $\begin{array}{l}28.02 \\
\pm 0.17\end{array}$ & $\begin{array}{c}2.18 \\
\pm 0.11\end{array}$ & $\begin{array}{c}0.52 \\
\pm 0.41\end{array}$ & $\begin{array}{l}53.41 \\
\pm 0.21\end{array}$ & $\begin{array}{c}5.16 \\
\pm 0.02\end{array}$ & $\begin{array}{c}5.16 \\
\pm 0.04\end{array}$ & $\begin{array}{l}11.15 \\
\pm 0.01\end{array}$ \\
\hline $\mathrm{AMF}+\mathrm{AZ}$ & $\begin{array}{l}32.17 \\
\pm 0.22\end{array}$ & $\begin{array}{c}2.20 \\
\pm 0.12\end{array}$ & $\begin{array}{c}1.02 \\
\pm 0.12\end{array}$ & $\begin{array}{l}66.31 \\
\pm 0.14\end{array}$ & $\begin{array}{c}6.25 \\
\pm 0.04\end{array}$ & $\begin{array}{c}6.21 \\
\pm 0.03\end{array}$ & $\begin{array}{l}11.25 \\
\pm 0.02\end{array}$ \\
\hline $\mathrm{AMF}+\mathrm{PSB}$ & $\begin{array}{l}36.22 \\
\pm 0.09\end{array}$ & $\begin{array}{c}2.30 \\
\pm 0.04\end{array}$ & $\begin{array}{c}1.26 \\
\pm 0.12\end{array}$ & $\begin{array}{l}70.05 \\
\pm 0.31\end{array}$ & $\begin{array}{c}6.33 \\
\pm 0.02\end{array}$ & $\begin{array}{c}6.33 \\
\pm 0.06\end{array}$ & $\begin{array}{l}11.66 \\
\pm 0.02\end{array}$ \\
\hline $\begin{array}{c}\mathrm{AMF}+\mathrm{AZ} \\
+\mathrm{PSB}\end{array}$ & $\begin{array}{l}40.24 \\
\pm 0.20\end{array}$ & $\begin{array}{c}2.46 \\
\pm 0.02\end{array}$ & $\begin{array}{c}1.31 \\
\pm 0.18\end{array}$ & $\begin{array}{l}74.04 \\
\pm 0.03\end{array}$ & $\begin{array}{c}6.77 \\
\pm 0.04\end{array}$ & $\begin{array}{c}6.43 \\
\pm 0.01\end{array}$ & $\begin{array}{l}12.40 \\
\pm 0.01\end{array}$ \\
\hline
\end{tabular}

In particular P deficiency has been described as a main factor in restricting not only plant development but other biological process such as nitrogen fixation, owing to high requirement of $\mathrm{P}$ deficiency has been described as a main factor in restricting not only plant development but other biological processes such as biological nitrogen fixation, owing to the high requirement of P (as ATP) for the nitrogen fixation process (Giller K.E, and Cadish G., 1955).

The analysis that phosphorous is present in less available forms could be a factor limiting the bacterial survival. In this context, the role of AM fungi as phosphorous suppliers to the plant appears to be of great relevance. 
Figures. Showing the effect of AM Fungi, PSB (Bacillus polymyxa) Azospirillium brasilense, on the growth response of Eleusine Coracana (Finger millet).

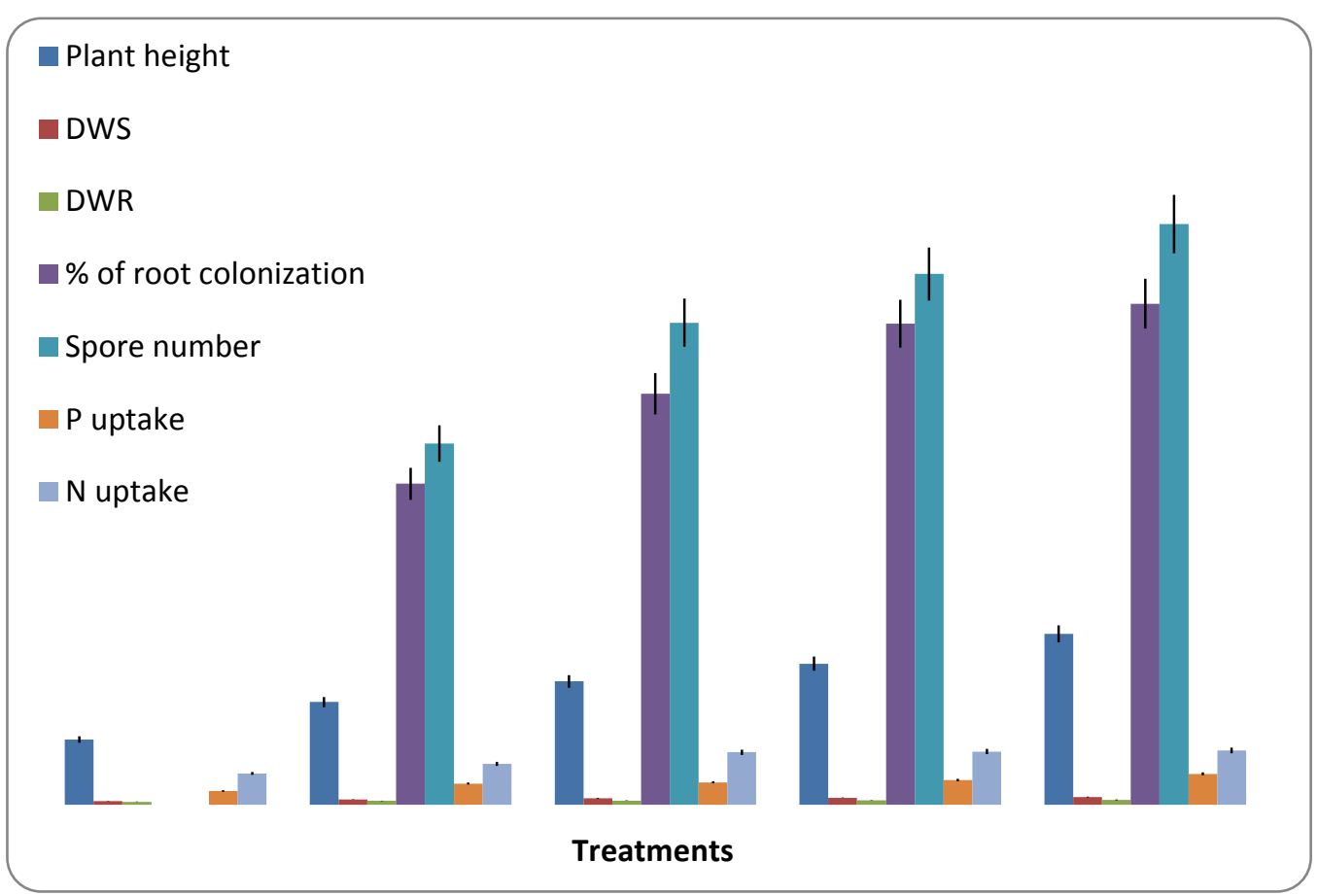

Fig. A.

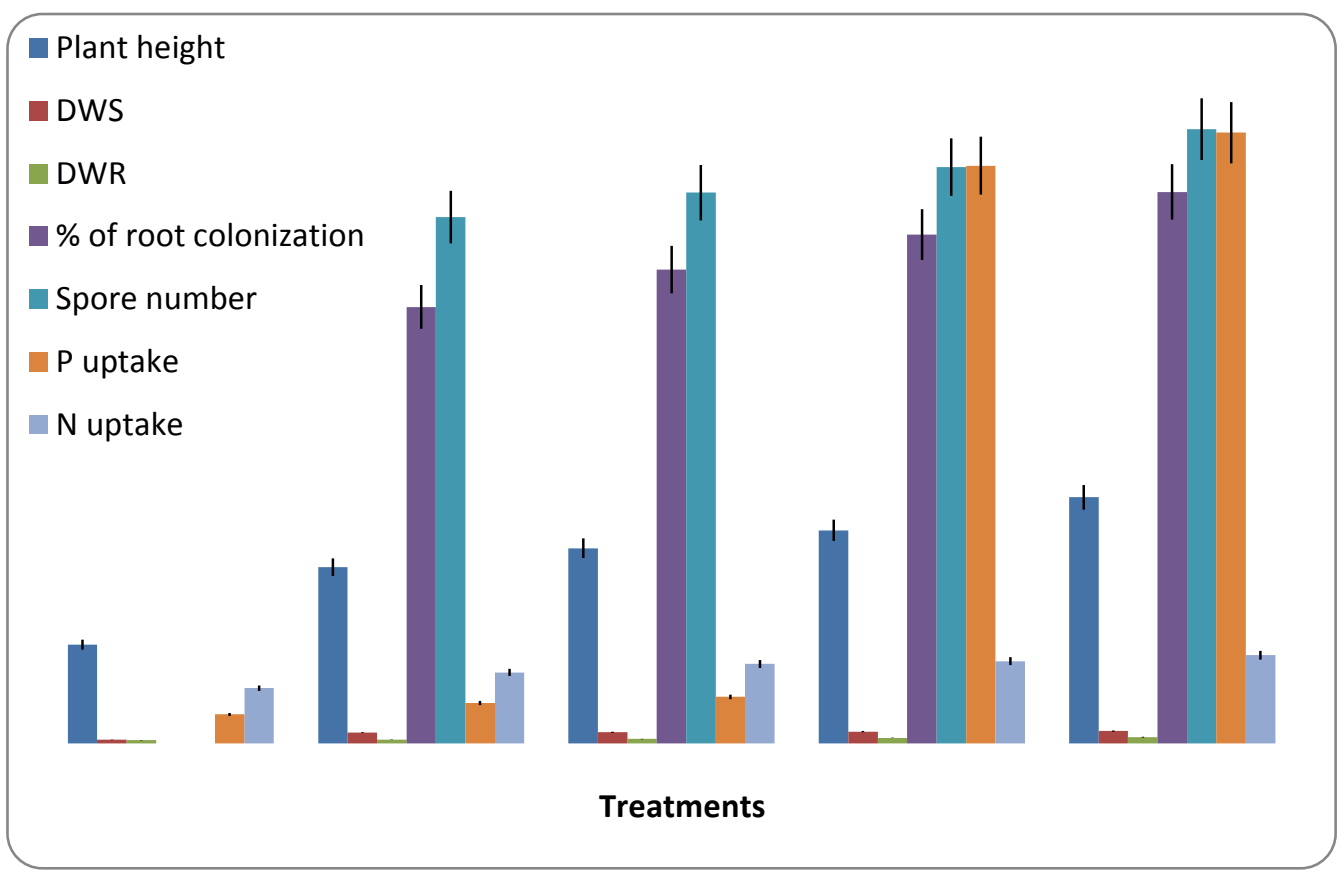

Fig. B. 


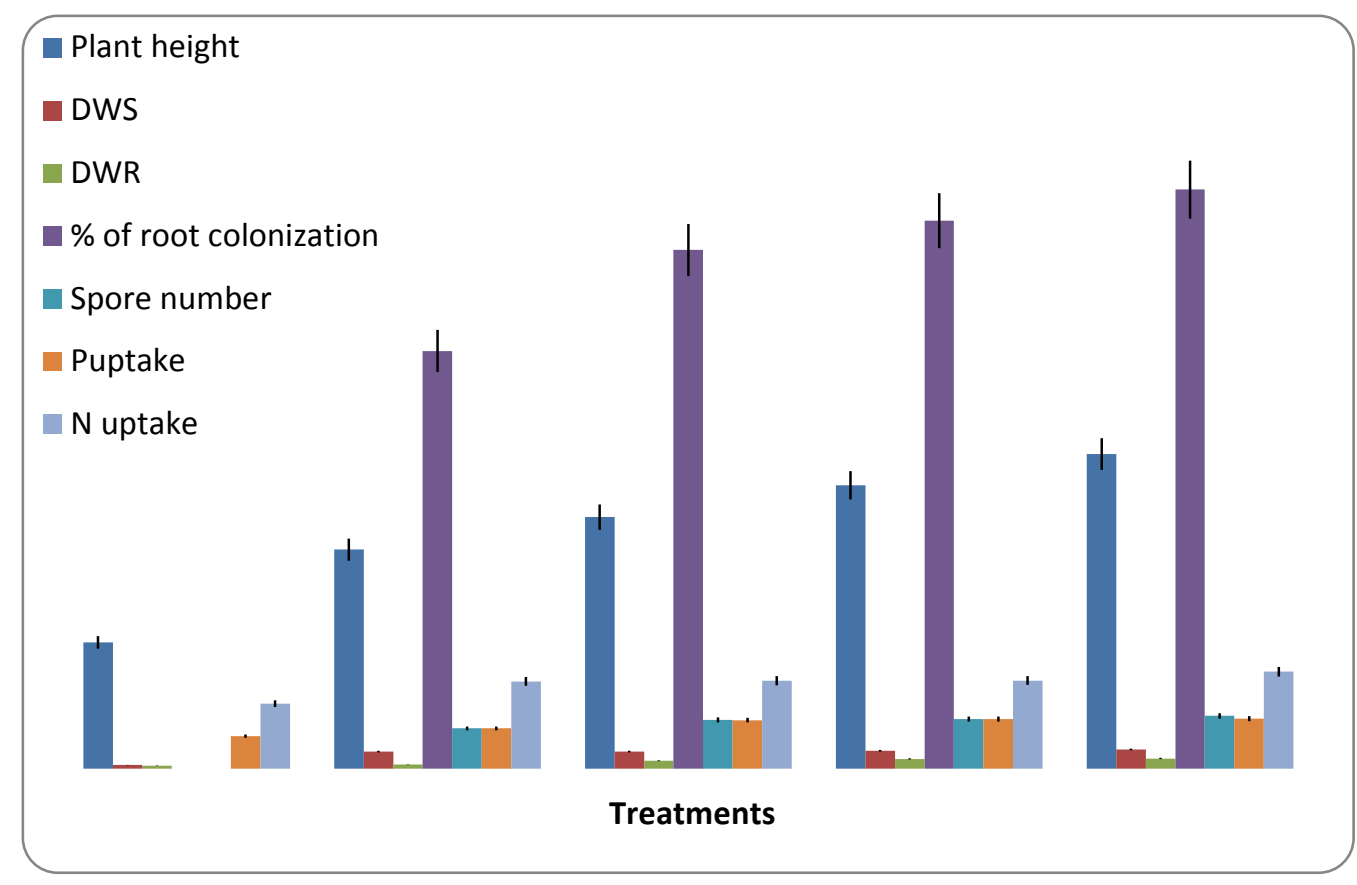

Fig. C.

In particular P deficiency has been described as a main factor in restricting not only plant development but other biological process such as nitrogen fixation, owing to high requirement of $\mathrm{P}$ deficiency has been described as a main factor in restricting not only plant development but other biological processes such as biological nitrogen fixation, owing to the high requirement of P (as ATP) for the nitrogen fixation process (Giller K.E, and Cadish G., 1955). The analysis that phosphorous is present in less available forms could be a factor limiting the bacterial survival. In this context, the role of AM fungi as phosphorous suppliers to the plant appears to be of great relevance.

Thus in finger millet inoculation with AM fungi, Azospirillium brasilense and Bacillus polymyxa produced highest effect on either plant growth or nutrient uptake, together with a noticeable increase in mycorrhizal root colonization. The positive effect of Azospirillum inoculation is mainly attributed to improved root development and subsequent increase in the rate of water and mineral uptake. The symbiotic relationship between AMF and the roots of higher plants contributes significantly to plant nutrition and growth (Auge, 2001), and has been shown to increase the productivity of a variety of agronomic crops. These positive responses in productivity to AM colonization have mainly been attributed to the enhanced uptake by AM of relatively immobile soil ions (Marschner and Dell, 1994; Liu et al., 2000), but also involve the enhanced uptake and transport of far more mobile nitrogen (N) ions, particularly under drought conditions (Tobar et al., 1994).

Root colonization by $A M$ fungi has been studied to increase absorption of minerals, particularly immobile nutrients, from soil by the host. Likewise, Azospirillum, one of the beneficial bacterial strains are known to play a pivotal role in fixing nitrogen in the roots by harnessing the atmospheric nitrogen and also have been reported to improve the fertility of soil. Beneficial bacterial flora can directly influence the physiology of the plants and in addition to interacting directly to beneficially influence the mycorrhizal relationship and/or plant growth (Johansson J. F., et al., 2004) specific bacteria together with AM fungi have been 
studied to create a more indirect synergism that supports plant growth including nutrient acquisition (Artursson V., et. al., 2006) inhibition of plant pathogenic fungi, and enhancement of root branching( Gamalero E, Martinotti M. G. 2004). In addition, most plant roots are colonized by mycorrhizal fungi and their presence also generally stimulates plant growth. However, most studies have reported the beneficial traits of root-colonizing bacteria and fungi separately and very few reports have demonstrated the synergistic effects of bacteria and $A M$ fungi with respect to their combined beneficial impacts on plants. Combined inoculation with $\mathrm{N}_{2}$ fixing and phosphate solubilizing bacteria was more effective than single microorganism for providing a more balanced nutrition for plants (Belimov et al., 1995).

Dual inoculation increased yields in sorghum (Algawadi \& Gaur, 1992), barley (Belimov et al., 1995), black gram (Tanwar et al., 2002), soybean (Abdalla \& Omar, 2001) and wheat (Galal, 2003). Beneficial effects of $A M$ fungal inoculation in terms of fruit production were more pronounced in combined inoculation. Cecilia et.al. (2004) reported wheat grains harvested from Azospirillium-inoculated plants contained significantly higher $\mathrm{Mg}, \mathrm{K}$, and $\mathrm{Ca}$ than non-inoculated plants. They also proved that grain yield loss to drought was 26.5 and $14.1 \%$ in non-inoculated and Azospirillium-inoculated plants respectively.

\section{CONCLUSIONS}

In the present study, the inoculation of AM fungi, PSB and Azospirillum have probably acted similarly bringing about an increase growth and yield in finger millet. It is inferred that under appropriate management, the use of more efficient bio fertilizers have lead to an increased growth and biomass of finger millet. The result have clearly shown that the combined application of bioinculants like Azospirillium + Azotobacter + AM fungi played a significant role in improving the growth response and nutrient uptake of finger millet seedlings thereby producing good quality planting stock. Phosphate-solubilizing bacteria play an important role in plant nutrition through the increase in $\mathrm{P}$ uptake by the plant, and their use as PGPR is an important contribution to bio fertilization of agricultural crops. Accordingly, further investigation is needed to improve the performance and use of phosphate-solubilizing bacteria as bacterial inoculants. Greater attention should be paid to studies and application of new combinations of phosphate solubilizing bacteria and other PGPR for improved results.

The mechanisms explaining the synergistic interaction should be a matter of further research to elucidate the biochemical basis of these interactions. These seedlings may perform better growth, survival and more biomass production in nutrient impoverished soil.

\section{Reference}

[1] Abdalla M. H., S. A. Omer, J. Plant Nut. 24 (2001) 261-72.

[2] Anonymous, 1997, A Guide to field implementation of integrated plant nutrition system. IFFCO, pp. 55-69. Artursson V., Finlay R. D., Jansson J. K., Environmental Microbiology, 2006.

[3] Auge R.M., Mycorrhiza 11 (2001) 3-42.

[4] Belimov A. A., P. A. Kojemiakov, C. V. Chuvarliyeva, Plant Soil 17 (1995) 29-37.

[5] Biswas B. C., Yadav D. S., Satish Maheshwari, Fertilizer News 30(10) (1985) 20-28. 
[6] Bremner J. M., Journal of Agricultural Science 55 (1960) 11.

[7] Cecilia M. C., R. J .Sueldo, C. A. Barassi, J. Bot. 82 (2004) 273-281.

[8] Gamalero E, Martinotti M. G, Trotta A., Lemanceau P., Berta G., New Phytologist, 155 (2004) 293.

[9] Galal Y. G. M., Egyptian J. Microbiol. 38 (2003) 57-73.

[10] Gerdemann J. W., Nicolson, T. H., Transaction of British Mycological Society 46 (1963) 235.

[11] Harley J. L., Harley E. L., New Phytol. 105 (1987) 1.

[12] Jeffries P., CRC Critical review of biotechnology 5 (1987) 319.

[13] Johansson J. F., Paul L. R., Finlay R. D., FEMS Microbiology Ecology 48 (2004) 1.

[14] Katyal J. C., Venkatashwarlu B., Das S. K., Fertiliser News 39(4) (1994) 27-32.

[15] Lakshman H. C., Int. J. Plant Sci. 1(1) (2009) 120.

[16] Liu A., Hamel C., Hamilton R. I., Smith D. L., Plant Soil 221 (2000) 157-166.

[17] Marschner H., Dell B., Plant Soil 159 (1994) 89-102.

[18] Philips J. M., Hayman D. S., Trans, Br. Mycol. Soc. 55 (1970) 158.

[19] Schenck N. C., Perez Y., Manual for the identification of VA Mycorrhizal fungi. In VAM Florida, University of Gainesville, USA, 1990, p. 245.

[20] Smith F. A., Smith S. E., Advanced Botany Research 21 (1996) 1.

[21] Tabatabai M. A. (1994). Soil enzymes. In: Weaver, R.W., Angle, G.S., Bottomley, P.S., Bezdicek, D., Smith, S., Tabatabai, M.A., Wollum, A. (Eds.), Methods of Soil Analysis: Part 2. Microbiological and Biochemical Properties of Soils. Soil Science Society of America, Madison, WI, pp. 775-833.

[22] Venkatashwarlu B. (2008). Role of bio-fertilizers in organic farming: Organic farming in rain fed agriculture: Central institute for dry land agriculture, Hyderabad. pp. 85-95.

[23] Wani S. P., Lee K. K. (1995). Microorganisms as biological inputs for sustainable agriculture in Organic Agriculture (Thampan, P. K. ed.) Peekay Tree Crops Development Foundation, Cochin, India. Pp. 39-76. 